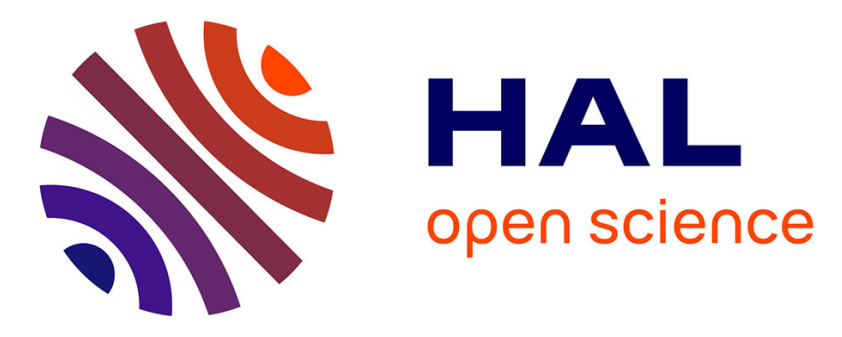

\title{
Intra-specific differences in allometric equations for aboveground biomass of eastern Mediterranean Pinus brutia
}

\author{
Sergio De-Miguel, Timo Pukkala, Nabil Assaf, Zuheir Shater
}

\section{To cite this version:}

Sergio De-Miguel, Timo Pukkala, Nabil Assaf, Zuheir Shater. Intra-specific differences in allometric equations for aboveground biomass of eastern Mediterranean Pinus brutia. Annals of Forest Science, 2014, 71 (1), pp.101-112. 10.1007/s13595-013-0334-4 . hal-01098388

\section{HAL Id: hal-01098388 \\ https://hal.science/hal-01098388}

Submitted on 24 Dec 2014

HAL is a multi-disciplinary open access archive for the deposit and dissemination of scientific research documents, whether they are published or not. The documents may come from teaching and research institutions in France or abroad, or from public or private research centers.
L'archive ouverte pluridisciplinaire HAL, est destinée au dépôt et à la diffusion de documents scientifiques de niveau recherche, publiés ou non, émanant des établissements d'enseignement et de recherche français ou étrangers, des laboratoires publics ou privés. 


\title{
Intra-specific differences in allometric equations for aboveground biomass of eastern Mediterranean Pinus brutia
}

\author{
Sergio de-Miguel • Timo Pukkala • Nabil Assaf • \\ Zuheir Shater
}

Received: 6 May 2013 / Accepted: 1 October 2013 /Published online: 25 October 2013

(C) INRA and Springer-Verlag France 2013

\begin{abstract}
- Context Biomass prediction is important when dealing for instance with carbon sequestration, wildfire modeling, or bioenergy supply. Although allometric models based on destructive sampling provide accurate estimates, alternative speciesspecific equations often yield considerably different biomass predictions. An important source of intra-specific variability remains unexplained.

- Aims The aims of the study were to inspect and assess intraspecific differences in aboveground biomass of Pinus brutia Ten. and to fill the gap in knowledge on biomass prediction for this species.

- Methods Two hundred one trees between 2.3 and $55.8 \mathrm{~cm}$ in diameter at breast height were sampled throughout the easternand southernmost natural distribution area of P. brutia, in Middle East, where it forms different stand structures.
\end{abstract}

Handling Editor: Shuqing Zhao

Contribution of the co-authors Sergio de Miguel: sampling design, data analysis, writing, research project coordination.

Timo Pukkala: sampling design, data analysis, writing, scientific supervision.

Nabil Assaf: sampling design, data collection, field work supervision. Zuheir Shater: sampling design, data collection, field work supervision.

S. de-Miguel $(\triangle) \cdot T$. Pukkala

Faculty of Science and Forestry, University of Eastern Finland, P.O. Box 111, 80101 Joensuu, Finland

e-mail: sergio.demiguel@uef.fi

N. Assaf

Food and Agriculture Organization of the United Nations (FAO),

B.P. 270 Alger RP, 16000Alger Gare, Algiers, Algeria

\section{Z. Shater}

Department of Forestry and Ecology, Faculty of Agriculture,

University of Tishreen, Latakia, Syria
Allometric equations were fitted separately for two countries. The differences in biomass prediction at tree, stand, and forest level were analyzed. The effect of stand structure and past forest management was discussed.

- Results Between-country differences in total aboveground biomass were not large. However, differences in biomass stock were large when tree components were analyzed separately. Trees had higher stem biomass and lower crown biomass in dense even-aged stands than in more uneven-aged and sparse stands.

- Conclusion Biomass and carbon predictions could be improved by taking into account stand structure in biomass models.

Keywords Allometry · Biomass allocation · Allometric models $\cdot$ Carbon sequestration $\cdot$ Biomass prediction $\cdot$ Pine . Stand structure

\section{Introduction}

Many important forest policy issues such as climate change mitigation and forest biomass as a source of renewable energy need knowledge on the biomass and carbon stock of forests (Henry et al. 2011). High-resolution methods proposed by the Intergovernmental Panel on Climate Change (IPCC 2006) to estimate forest biomass require species-specific biomass models based on country-specific data. In addition, models for specific components of the tree (i.e., needle, branch, crown) are also of interest for fuel loading prediction and wildfire modeling and simulation (e.g., Gray and Reinhardt 2003) in typically fire-prone forest ecosystems such as the eastern Mediterranean Pinus brutia Ten. forests. 
Since forest management and planning should currently consider also biomass and carbon issues, models enabling the prediction of biomass and carbon stock are required for all common tree species. A well-known approach is to fit treelevel allometric equations for the main components of trees (foliage, branches, stem, and roots) that enable, in combination with individual-tree growth models, to compute biomass and carbon stock predictions at multiple scales (tree, stand, forest, region, country).

Many previous studies have proposed biomass models for tree species throughout the world (e.g., see Jenkins et al. 2003; Zianis et al. 2005; Henry et al. 2011). However, despite its evident importance as the most widespread conifer species in the eastern Mediterranean, $P$. brutia has not been the subject of active research in this field. For example, $P$. brutia was not included within the 607 biomass equations compiled by Zianis et al. (2005) for about 40 tree species in Europe. Only a few recent studies have tackled the prediction of aboveground biomass for this species in restricted areas of Turkey (Durkaya et al. 2009) and in two Greek islands (Zianis et al. 2011). Other studies have provided local allometric equations for tree crown biomass components based on P. brutia trees smaller than $20 \mathrm{~cm}$ in diameter at breast height (dbh) (Küçük and Bilgili 2007; Küçük et al. 2008; Bilgili and Kucuk 2009). As a consequence, large areas within the natural distribution area of $P$. brutia remain without tools for a science-based estimation of aboveground biomass and carbon. Differences in tree shape among locations and provenances due to environmental factors (Zianis et al. 2011) or genetic variation (Isik et al. 1999) prevent the extrapolation of the above-mentioned local equations to other areas.

Henry et al. (2011) also pointed out the existence of an important source of unexplained intra-specific variability in biomass estimates among different equations for many forest species as a result of both environmental and anthropogenic factors. Previous research on other species has shown that biomass allocation may depend on site factors (Crow 1978; Ketterings et al. 2001), stage of stand development (Porté et al. 2002; António et al. 2007; Peichl and Arain 2007; Tinker et al. 2010), stand density (Tinker et al. 2010), and within-stand competitive status of the tree (Naidu et al. 1998). This suggests that biomass models should be developed for specific tree species and stand structures (Ter-Mikaelian and Korzukhin 1997). Despite this, biomass and carbon stocks in different tree components are generally predicted using the same allometric relationships, regardless of the stand structure and forest management regime, especially when fixed-effect models are used or mixed-effect models are not calibrated for a particular site or stand. In the case of mixed-effects models (e.g., Repola 2009), random effects may partly account for the influence of stand structure.

P. brutia forests occurring in Syria and Lebanon constitute two non-connected populations that have been subjected to different past forest management regimes according to different forest policies, which in turn have shaped the forest stand structures ranging from mostly unthinned even-aged stands in Syria to more sparse multilayered and uneven-aged stand structures in Lebanon (Fig. 1) (de-Miguel et al. 2010, 2012b). Since cutting of living trees is strictly forbidden in Syria, most Syrian stands are on the self-thinning limit. On the other hand, many Lebanese stands have been selectively cut which, in combination with wildfires, has resulted in regeneration and the formation of two- to multi-layered stand structures. P. brutia forests in Middle East therefore represent an interesting topic for analyzing the link between forest management, stand structure, and biomass and carbon prediction. The aims of this article are: (1) to provide allometric biomass equations for $P$. brutia for evenand uneven-aged stands and (2) to discuss the effect of forest management-induced stand structure on biomass and carbon allocation.
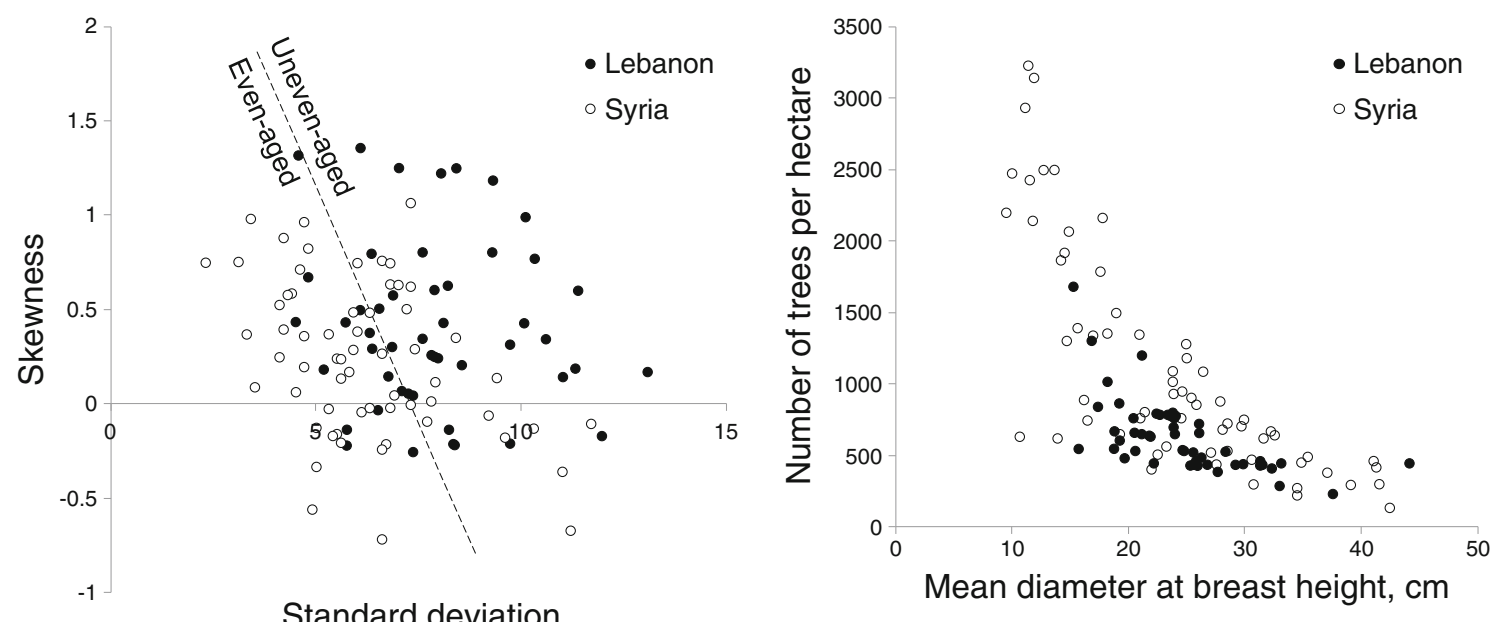

Fig. 1 Differences $(p$ value $<0.05$ ) in stand structure between Lebanese and Syrian $P$. brutia forests according to skewness and standard deviation of the diameter distribution (de-Miguel et al. 2012b) and stand density 


\section{Material and methods}

\subsection{Sampling}

Among the different possibilities for assessing tree biomass on large spatial scales, sampling trees covering a wide range of variation throughout the target territory can produce models that enable sound predictions and ensure an unbiased sample of trees (Jenkins et al. 2003; Muukkonen 2007). Destructive sampling is considered the most accurate method to produce reliable biomass data (Henry et al. 2011). In this study, altogether $201 P$. brutia trees of different sizes and shapes were felled in Syria (100 trees) and Lebanon (101 trees) beside sample plots used for growth and yield modeling by deMiguel et al. (2010, 2012a, b) and by Shater et al. (2011). Sample trees (Table 1) represented different growing sites, stand densities, and stand ages. Every tree was measured for $\mathrm{dbh}(1.3 \mathrm{~m})$, total tree height, crown length, and stem diameters at the following relative heights $1,5,10,20, \ldots 90 \%$ of total tree height. All branches of each tree were collected into bundles, the fresh mass of which were measured in the field with a spring balance. The fresh weight of the crown was measured by weighing branches and needles together. A cubic spline function was fitted for each tree to calculate the stem diameter at $10-\mathrm{cm}$ intervals. The volume of each $10-\mathrm{cm}$ disk was calculated with the cylinder formula and summed to obtain the total stem volume.

To determine the dry matter content, samples of branches and needles of about $1.5 \mathrm{~kg}$ each were taken from 28 trees. The samples were dried in the oven at $105{ }^{\circ} \mathrm{C}$ until they reached constant weight. The average dry matter content of branches and needles ( 0.49 and 0.45 , respectively) was multiplied by the corresponding fresh biomass of every sample tree in order to calculate the dry biomass for these components. Finally, to determine the basic density of the tree stem, 37 stem disks were taken from trees of different sizes. The samples were also dried in oven, and the basic density was calculated by dividing the obtained dry weight by the fresh volume of the disk. The stem dry biomass of every tree stem was then computed by multiplying the total stem volume by

Table 1 Summary of data used in aboveground biomass modeling

\begin{tabular}{llll}
\hline Variables & Minimum & Mean & Maximum \\
\hline Diameter at breast height $(\mathrm{cm})$ & 2.3 & 22.4 & 55.8 \\
Tree height $(\mathrm{m})$ & 3.1 & 12.8 & 32.5 \\
Crown length $(\mathrm{m})$ & 2.0 & 7.7 & 16.2 \\
Dry matter in needles $\left(\mathrm{kg} \mathrm{tree}^{-1}\right)$ & 0.2 & 18.4 & 98.5 \\
Dry matter in branches $\left(\mathrm{kg} \mathrm{tree}^{-1}\right)$ & 0.3 & 47.1 & 285.3 \\
Dry matter in stem $\left(\mathrm{kg} \mathrm{tree}^{-1}\right)$ & 0.5 & 184.4 & $1,333.3$ \\
Total dry matter $\left(\mathrm{kg} \mathrm{tree}{ }^{-1}\right)$ & 1.0 & 250.0 & $1,588.1$ \\
\hline
\end{tabular}

the basic density. The average basic density of the samples $\left(0.519 \mathrm{~kg} / \mathrm{dm}^{3}\right)$ was used to convert stem volume into stem biomass.

Since needles were not separated from branches, the proportion of branches of the total fresh biomass of tree crown was calculated from $p$ (branch) $=0.6+0.003 d$, where $d$ is $\mathrm{dbh}$ in centimeters. The formula is based on the information presented by Montero et al. (2005) for Pinus halepensis (the equivalent species of $P$. brutia in the western Mediterranean). This gives a branch proportion of $66 \%$, of the total fresh mass of branches and needles, when dbh equals $20 \mathrm{~cm}$. In the samples taken to laboratory for the determination of dry matter content, the share of branches was $64 \%$ in Lebanon and $67 \%$ in Syria.

\subsection{Selection of candidate models}

Numerous allometric equations have been proposed to estimate the biomass stored in different tree components. The number of predictors used in different models may range from one single variable (diameter at breast height) to several variables (e.g., tree height, tree crown length, tree crown width). The aim was to fit models separately for the following tree components of aboveground biomass: stem, branches, needles, and crown (branches + needles). Since the tree-level information available from the $P$. brutia datasets were diameter at breast height, tree height, and crown length, we tested 16 models among the most utilized in previous research dealing with biomass prediction (e.g., Zianis et al. 2005) and including different combinations of the above-mentioned predictors (Table 2). Since the information provided by field measurements varies considerably between forest inventories, two alternative models were provided for each aboveground tree component: one of the models being the best possible combination of the available predictors and the other model being the best equation when using dbh as the only predictor. Predictions at tree, stand, and forest level were based on the latter model form.

\subsection{Statistical analysis}

The equations presented in this study were fitted under the intrinsically linear form (Návar 2010). Many models provided in the literature concerning biomass prediction use logarithmic transformation of the response variable (Table 2), based on the assumption of a lognormal distribution. Nevertheless, making transformations generally causes biased predictions for the back-transformed variable. Although there are different methods to cope with this drawback (e.g., Baskerville 1972), bias (and, hence, the use of correction factors) can be avoided by fitting models using nonlinear regression analysis. For this reason, the intrinsically linear models presented in this study were fitted by means of nonlinear regression analysis using generalized least squares, yielding predictions for the response 
Table 2 Tested allometric equations, where $y$ is dry biomass (in kilograms per tree), $d$ is diameter at breast height (in centimeters), $h$ is tree height (in meters), and $c l$ is crown length (in meters)

\begin{tabular}{ll}
\hline Equation number & Expression \\
\hline 1 & $\ln y=b_{0}+b_{1} \cdot \ln d$ \\
2 & $\ln y=b_{0}+b_{1} \cdot \ln d+b_{2} \cdot \ln h$ \\
3 & $\ln y=b_{0}+b_{1} \cdot \ln d+b_{2} \cdot \ln c l$ \\
4 & $\ln y=b_{0}+b_{1} \cdot \ln d+b_{2} \cdot h+b_{3} \cdot \ln h$ \\
5 & $\ln y=b_{0}+b_{1} \cdot d+b_{2} \cdot \ln d+b_{3} \cdot h$ \\
6 & $\ln y=b_{0}+b_{1} \cdot \ln \left(d^{2} \cdot h\right)$ \\
7 & $\ln y=b_{0}+b_{1} \cdot \ln d+b_{2} \cdot \ln \left(d^{2} \cdot h\right)$ \\
8 & $\ln y=b_{0}+b_{1} \cdot(\ln d)^{2}+b_{2} \cdot \ln \left(d^{2} \cdot h\right)$ \\
9 & $\ln y=b_{0}+b_{1} \cdot \ln d+b_{2} \cdot \ln d^{2}+\ln h$ \\
10 & $\ln y=b_{0}+b_{1} \cdot \ln d+b_{2} \cdot \ln h+b_{3} \cdot \frac{d}{h^{2}}$ \\
11 & $\ln y=b_{0}+b_{1} \cdot \frac{d}{d+b_{2}}$ \\
12 & $\ln y=b_{0}+b_{1} \cdot \frac{d}{d+b_{2}}+b_{3} \cdot h$ \\
13 & $\ln y=b_{0}+b_{1} \cdot \frac{d}{d+b_{2}}+b_{3} \cdot \ln h$ \\
14 & $\ln y=b_{0}+b_{1} \cdot \frac{d}{d+b_{2}}+b_{3} \ln c l$ \\
15 & $\ln y=b_{0}+b_{1} \cdot \frac{d}{d+b_{2}}+b_{3} \cdot h+b_{4} \cdot \ln h$ \\
16 & $\ln y=b_{0}+b_{1} \cdot \frac{d}{d+b_{2}}+b_{3} \ln h+b_{4} \ln c l$ \\
\hline &
\end{tabular}

variable on its original scale. This approach is presumed to also prevent the so-called additivity problem (Parresol 2001) arising from the mismatch between the sum of component-based predictions and total biomass estimates (Snowdon et al. 2000).

The statistical analyses were carried out using the nlme and stats packages in $\mathrm{R}$ software (R Development Core Team 2011). A power-type variance function was used to homogenize the residual variance:

$\operatorname{var}\left(e_{i}\right)=\sigma^{2} \cdot|y|^{2 \cdot \delta}$

where $\sigma^{2}$ is the error variance, $y$ represents a variance covariate given by the fitted values of the model, and $\delta$ is the variance function coefficient.

\subsection{Model evaluation}

Several evaluation criteria were considered when choosing the best models for the different tree components: (a) statistical significance ( $p$ value $<0.05$ ), (b) minimum residual standard error (RSE), (c) non-biasness, (d) homoscedasticity and normal distribution of residuals, (e) parsimony, (f) acceptable levels of collinearity, and $(\mathrm{g})$ agreement with current biological knowledge. As an additional test to check the absence of biased predictions due to the additivity problem, the crown biomass estimates computed from the sum of the separate predictions for the tree components were compared with the predictions directly obtained from a model fitted for the total aboveground biomass. The Akaike information criterion and the Bayesian information criterion were used in model selection, and likelihood ratio tests were carried out in order to assess whether the improvement caused by adding predictors to a null model was statistically significant. The mean square deviation (MSD) was partitioned into several additive error components allowing us to identify all sources of discrepancy from perfect fit (Gauch et al. 2003). Tree- and forest-level predictions were based on models using $\mathrm{dbh}$ as the only predictor (Eqs. 20, 22, 24, 26, 30, 32, 34, and 36).

\section{Results}

The majority of the selected biomass models were of the following form (Table 3):

$y=e^{b_{0}+b_{1} \cdot \frac{d}{d+b_{2}}+c \cdot X}$

where $d$ is the diameter at breast height (in centimeters), $c$ is a vector containing the regression coefficients of any other predictor different than dbh, and $X$ is a vector containing predictors other than dbh.

All the predictors used in the selected models were highly significant ( $p$ value $<0.01$ ). Crown length was a significant predictor of crown biomass components in the dense evenaged Syrian stands, whereas it was not among the best predictors in the more sparse and uneven-aged stands of Lebanon. The reduction of the RSE between the models with several predictors and those using only dbh ranged from 11.7 to $49.6 \%$. This effect was, in general, lower for the needle and branch biomass and higher for the stem biomass. In all cases, the biomass equations fitted for Lebanese trees presented higher RSE than the equations fitted for Syrian trees. The RSE values were 15.1-47.5\% lower for Syrian trees than in Lebanon, depending on the biomass component. The highest between-country difference in terms of RSE corresponded to the crown biomass model with dbh as the only predictor (Eqs. 24 and 34). The lowest difference also corresponded to the equation for crown biomass, but to the one using more than one predictor (Eqs. 23 and 33).

\subsection{Evaluation of the selected models}

When evaluating the predicted versus observed total biomass values of $P$. brutia trees, the root mean squared deviation (RMSD) and bias of the model for trees growing in Lebanese stands were 47.6 and $-0.4 \mathrm{~kg}$ tree $^{-1}$, respectively. The RMSD and bias of the model for Syrian trees were 52.4 and $3.3 \mathrm{~kg}$ tree $^{-1}$, respectively. The main source of discrepancy from perfect fit was due to the scattering of the observations around the predicted values (93 and $98 \%$ of the MSD in Syrian and Lebanese stands, respectively), whereas the contribution to 
Table 3 Best models for aboveground biomass components considering all predictors and only dbh, where $y$ is dry biomass (in kilograms per tree), $d$ is dbh (in centimeters), $h$ is tree height (in meters), $\mathrm{cl}$ is crown length (in meters), $\delta$ is the variance function coefficient, and RSE is the residual standard error

\begin{tabular}{|c|c|c|c|c|c|}
\hline Stand & Component & Model & $\delta$ & RSE & Eq.number \\
\hline \multirow[t]{10}{*}{ Syria } & Needles & $y=e^{-2.905+7.582 \cdot \frac{d}{d+19.782}+0.581 \cdot c l}$ & 0.945 & 0.369 & 19 \\
\hline & Needles & $y=e^{-2.302+8.865 \cdot \frac{d}{d+20.790}}$ & 0.924 & 0.418 & 20 \\
\hline & Branches & $y=e^{-1.794+10.665 \cdot \frac{d}{d+21.660}+0.845 \cdot \ln c l-0.824 \cdot \ln h}$ & 0.935 & 0.372 & 21 \\
\hline & Branches & $y=e^{-1.652+10.395 \cdot \frac{d}{d+26.816}}$ & 0.916 & 0.455 & 22 \\
\hline & Crown & $y=e^{-1.838+8.570 \cdot \frac{d}{d+24.443}+0.593 \cdot \ln c l}$ & 0.943 & 0.394 & 23 \\
\hline & Crown & $y=e^{-1.203+9.925 \cdot \frac{d}{d+25.316}}$ & 0.917 & 0.467 & 24 \\
\hline & Stem & $y=e^{-3.371+1.835 \cdot \ln d+0.937 \cdot \ln h}$ & 0.920 & 0.153 & 25 \\
\hline & Stem & $y=e^{-2.698+2.440 \cdot \ln d}$ & 0.960 & 0.239 & 26 \\
\hline & Total & $y=e^{-0.849+8.863 \cdot \frac{d}{d+15.048}+0.042 \cdot h}$ & 0.893 & 0.225 & 27 \\
\hline & Total & $y=e^{-2.310+2.389 \cdot \ln d}$ & 0.882 & 0.316 & 28 \\
\hline \multirow[t]{10}{*}{ Lebanon } & Needles & $y=e^{0.078+10.665 \cdot \frac{d}{d+26.492}-0.855 \cdot \ln h}$ & 0.952 & 0.442 & 29 \\
\hline & Needles & $y=e^{-0.820+8.279 \cdot \frac{d}{d+26.854}}$ & 0.801 & 0.752 & 30 \\
\hline & Branches & $y=e^{0.625+12.203 \cdot \frac{d}{d+30.900}-0.855 \cdot \ln h}$ & 0.953 & 0.455 & 31 \\
\hline & Branches & $y=e^{-0.253+9.921 \cdot \frac{d}{d+33.376}}$ & 0.824 & 0.811 & 32 \\
\hline & Crown & $y=e^{1.096+11.737 \cdot \frac{d}{d+29.832}-0.855 \cdot \ln h}$ & 0.953 & 0.464 & 33 \\
\hline & Crown & $y=e^{0.215+9.422 \cdot \frac{d}{d+31.814}}$ & 0.817 & 0.889 & 34 \\
\hline & Stem & $y=e^{-1.372+8.100 \cdot \frac{d}{d+25.960}+0.920 \cdot \ln h}$ & 0.917 & 0.185 & 35 \\
\hline & Stem & $y=e^{-0.622+10.187 \cdot \frac{d}{d+21.196}}$ & 0.897 & 0.367 & 36 \\
\hline & Total & $y=e^{0.406+8.991 \cdot \frac{d}{d+24.021}+0.030 \cdot h}$ & 0.737 & 0.681 & 37 \\
\hline & Total & $y=e^{0.474+9.791 \cdot \frac{d}{d+25.177}}$ & 0.793 & 0.547 & 38 \\
\hline \multirow[t]{9}{*}{ Middle East } & Needles & $y=e^{-0.572+11.470_{\frac{d}{d+18.755}}-1.179 \cdot \ln h}$ & 0.863 & 0.593 & 39 \\
\hline & Needles & $y=e^{-1.848+8.000 \cdot \frac{d}{d+16.803}}$ & 0.801 & 0.909 & 40 \\
\hline & Branches & $y=e^{0.113+12.790 \cdot \frac{d}{d+23.007}-1.166 \cdot \ln h}$ & 0.874 & 0.636 & 41 \\
\hline & Branches & $y=e^{-1.149+9.277 \cdot \frac{d}{d+22.206}}$ & 0.821 & 0.991 & 42 \\
\hline & Crown & $y=e^{0.554+12.372 \cdot \frac{d}{d+21.933}-1.168 \cdot \ln h}$ & 0.870 & 0.675 & 43 \\
\hline & Crown & $y=e^{-0.708+8.866 \cdot \frac{d}{d+20.838}}$ & 0.815 & 1.085 & 44 \\
\hline & Stem & $y=e^{-1.734+8.090 \cdot \frac{d}{d+20.731}+0.886 \cdot \ln h}$ & 0.861 & 0.227 & 45 \\
\hline & Stem & $y=e^{-2.779+2.427 \cdot \ln d}$ & 0.959 & 0.305 & 46 \\
\hline & Total & $y=e^{0.119+10.122 \cdot \frac{d}{d+23.225}}$ & 0.768 & 0.614 & 47 \\
\hline
\end{tabular}

the MSD due to squared bias was practically $0 \%$ (unbiased allometric equations), and the proportion of the MSD explained by the nonunity slope was also low ( 2 and $7 \%$ for the uneven-aged and even-aged case, respectively). The comparison between predicted total aboveground biomass calculated by adding the estimates of the different components and by direct estimation via an allometric model almost followed the perfect equality line. The mean difference between the prediction approaches was $-0.1 \mathrm{~kg}$ tree ${ }^{-1}$ for Lebanon and $-2.8 \mathrm{~kg} \operatorname{tre}^{-1}$ for Syria, which means that no remarkable additivity problems were found.

\subsection{Tree-level biomass predictions based on the selected} models

The contribution of each component to the total aboveground biomass varied according to tree size as shown in Figs. 2 and 3. The proportion of stem biomass is lower in small or young trees, whereas the proportion of crown biomass diminishes as the tree grows. A medium-sized pine growing in an unthinned even-aged stand is expected to have $30 \%$ more biomass in its stem than a medium-sized tree growing in a sparse and more irregular Lebanese stand. On the contrary, a medium-sized tree growing in Lebanon is expected to have $88.5 \%$ more biomass in its crown than a medium-sized tree in a Syrian stand. The statistical assessment by means of an indicator variable and by analysis of variance showed that the differences were significant for all aboveground tree components. On the other hand, no statistically significant differences were found for the total aboveground biomass of P. brutia (Fig. 3).

\subsection{Forest-level biomass predictions}

Assuming that the Syrian models represent even-aged stands grown without thinnings and the Lebanese models represent selection cutting systems resulting in uneven-aged stands, the 
models give an idea of the biomass distribution in these systems (Fig. 4). Such a calculation was done for a forest containing three age classes of even-aged stands and for a forest having a similar uneven-aged structure everywhere. The basal areas of the stands used in the calculation were typical values for Syrian and Lebanese P. brutia forests (Shater et al. 2011; de-Miguel et al. 2012b). The proportions of biomass components in the even-aged and uneven-aged forests reflected the proportions found at tree level. The contribution of stem biomass to the total aboveground biomass of the 20-, $40-$, and 60 -year-old age classes was $79.8,80.5$, and $80.6 \%$, and crown biomass represented 20.2, 19.5, and $19.4 \%$, respectively. The proportions of stem and crown biomass for the uneven-aged case were 61.8 and $38.1 \%$, respectively.

\section{Discussion}

This study highlights the importance of considering forest stand structure and past forest management practices when aiming at predicting biomass and carbon stock in different components, especially when dbh is used as the only predictor of tree biomass. Long-term simulations of carbon stock under different management regimes and stand structures (e.g., Bravo et al. 2008; del Río et al. 2008; Bragg and Guldin 2010; Pukkala et al. 2011) often assume that trees of a given species have a similar partitioning of biomass and carbon into

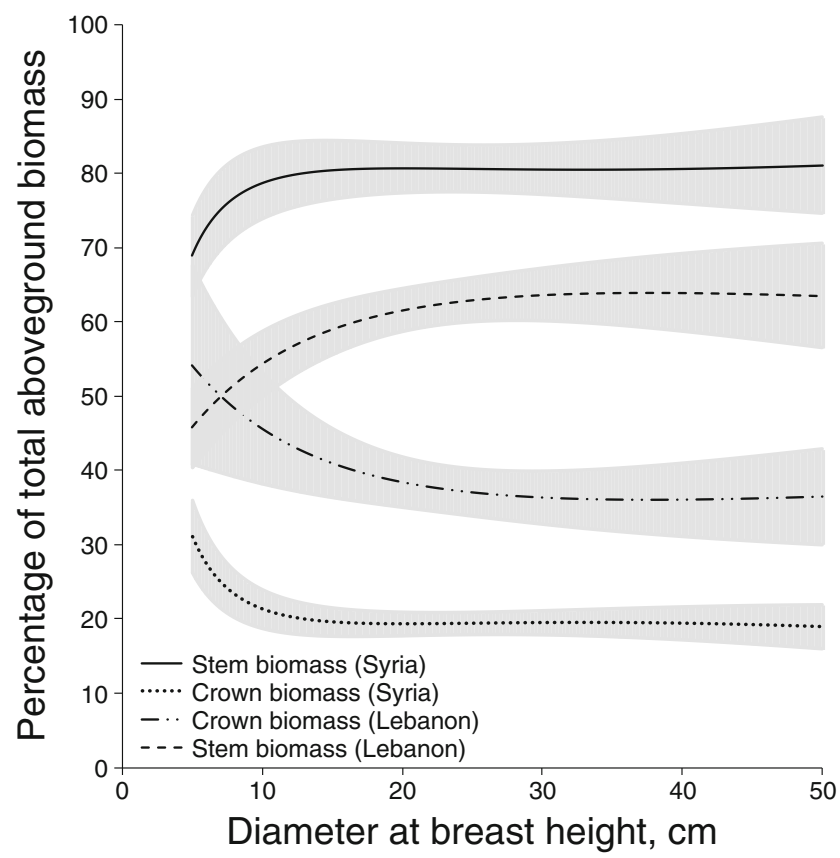

Fig. 2 Contribution of crown and stem tree components to total aboveground tree biomass as a function of tree size (dbh) in Syria and Lebanon. The gray areas show the range of variation of the percentage contribution with respect to the mean of each tree component based on the $95 \%$ confidence intervals of country-specific model predictions different components regardless of the stand structure or forest management regime. Our results show, however, that significant intra-specific differences in biomass and carbon allocation can be found in trees and stands managed under different silvicultural regimes. Considering these differences may contribute to improve the assessment of biomass and carbon in forest planning and long-term scenario analyses. The results and conclusions are based on sound aboveground biomass models for different tree components of $P$. brutia based on large-scale sampling.

\subsection{Performance of allometric equations and reliability of predictions}

One of the strengths of the fitted equations relies on the valuable sampling carried out within this research. As reported by Zianis et al (2005), more than $90 \%$ of the 607 equations included in the collection of biomass equations for tree species in Europe were based on a sample size smaller than the 201 trees sampled in this study (most data sets had six to 40 sample trees). The same authors stated that there are no equations from large geographical areas for Mediterranean forests, which constitutes and added value of this work. The few previous publications on P. brutia biomass (Bilgili and Kucuk 2009; Durkaya et al. 2009; Zianis et al. 2011) used a smaller sample of mature trees: 35,41 , and 18 trees, respectively. Chave et al. (2004) recommended that only allometric equations based on at least 100 trees should be used in biomass prediction, which was the case for all biomass models presented in this study. In addition, the sampling of this study covered a wider range of variation in tree size (dbh from 2.3 to $55.8 \mathrm{~cm}$ ) than in previous research. Particularly, the inclusion of a considerable number of trees with dbh below $10 \mathrm{~cm}$ makes it possible to provide unbiased biomass estimates also for small trees, which constitute a significant biomass component of the stand. This is especially important when dealing with fire-prone $P$. brutia forests, where detailed knowledge about fuel properties is needed for fire behavior prediction (Chave et al. 2004; Bilgili and Kucuk 2009). Systematic overestimation of aboveground biomass for small trees has been reported to occur when models are fitted using only large trees (van Breugel et al. 2011). The large sample and size variation of sample trees increased the precision of biomass estimates and enabled further inspection of tree allometry dynamics (Návar 2009). The basic density obtained from the $P$. brutia sample trees (average value of $0.519 \mathrm{~g} / \mathrm{m}^{3}$ ), on which the calculations of the observed biomass are partly based, was in line with those reported in other studies for the same species (e.g., Guller 2007).

Most of the selected equations were inspired by the model form proposed by Marklund (1987, 1988) (Eq. 11). Muukkonen (2007) also found that this equation had better fit than the most commonly used power equation due to its 

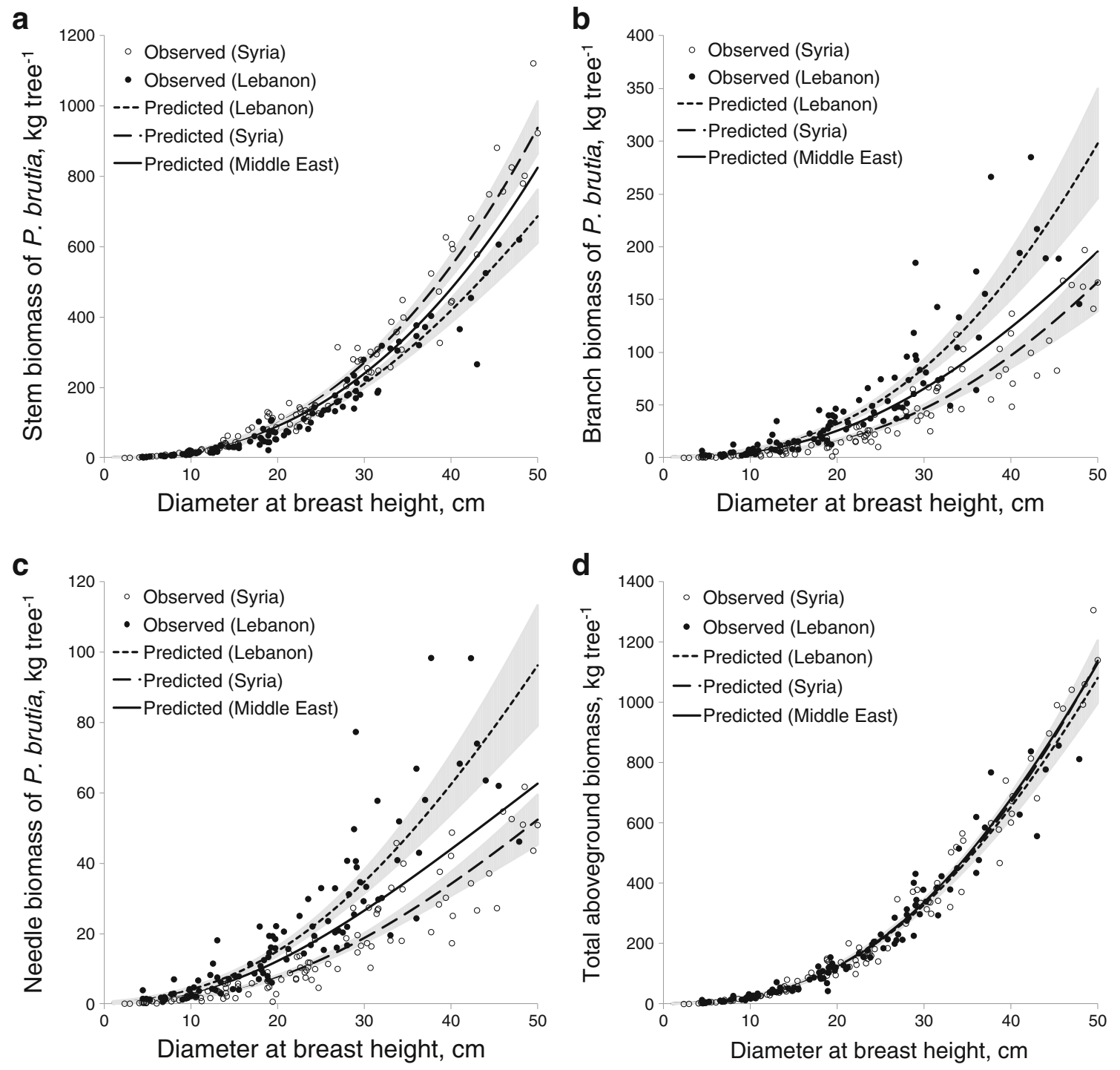

Fig. 3 Country-specific relationships between dbh and a stem, b branch, c needle, and $\mathbf{d}$ total biomass. The $95 \%$ confidence intervals for countryspecific allometric models are shown by the gray areas around the model

d

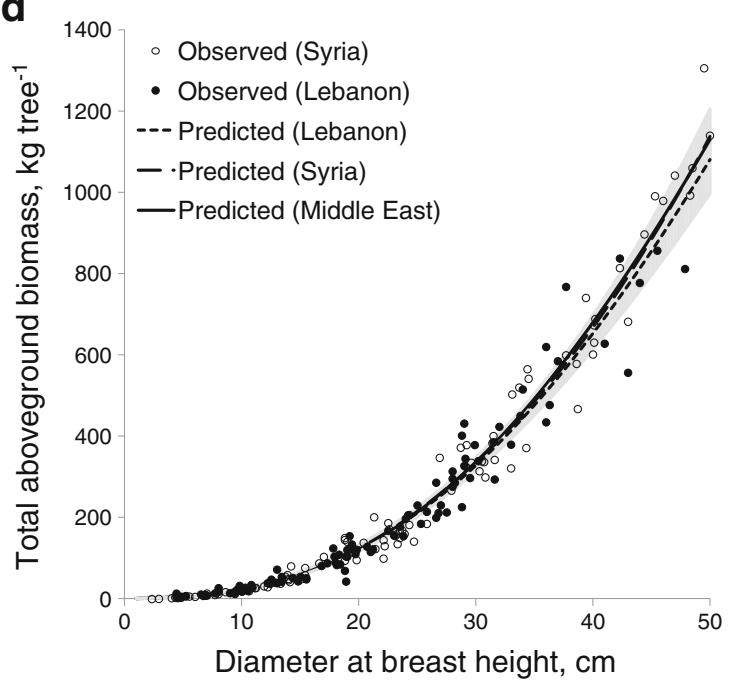

predictions. The thick solid line represents the predictions of the regional model based on pooled data (Lebanon+Syria)

higher flexibility when predicting biomass of small trees. As suggested by Chave et al. (2005), a power law does not seem to be the best way to predict tree allometric relationships. According to the differences in terms of RSE between equations for the same tree component, additional predictors in the model (i.e., tree height and crown length) had a stronger effect on the goodness of fit in the equations for Lebanon. This could be explained by higher heterogeneity in tree shape of pines growing in more uneven stand structures, needing additional variables to successfully describe tree size and shape. In the equations of António et al. (2007), the use of tree height as the second predictor decreased residual variation by $72 \%$ for stem wood biomass, $8 \%$ for stem bark, $12 \%$ for foliage, and $10 \%$ for branches. Chave et al. (2005) reduced the standard error of biomass estimates from 19.5 to $12.5 \%$ when tree height was included as a predictor. The use of predictors

accounting for the vertical tree and stand structure can improve the quality of the models and their potential applicability to different sites. Therefore, equations based on tree diameter as a single predictor should be used with caution (Ketterings et al. 2001; Chave et al. 2005). Increasing use of LIDAR in forest inventory will provide accurate predictions of tree height and crown dimensions, which will improve future individual-tree aboveground biomass estimations at stand, forest, and landscape level.

Model evaluation revealed that biomass predictions were accurate and nonbiased. Heteroscedasticity was modeled by means of a power-type variance function (Eq. 17), which improved significantly the fitting statistics of all biomass models. The regression coefficients of the selected models were consistent with the current biological knowledge. The equations using the simple power model (Eq. 1), presented 

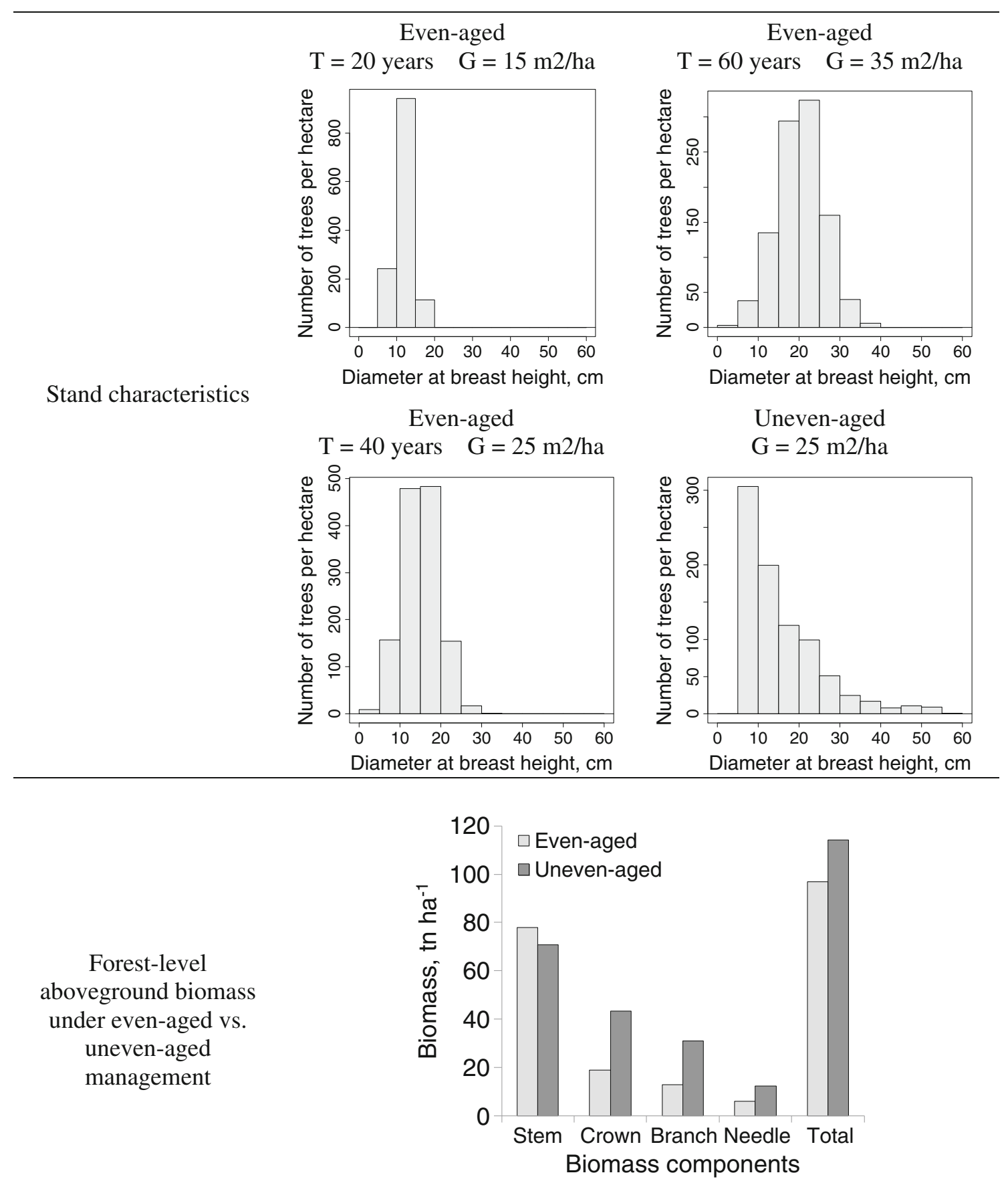

Fig. 4 Assessment of forest-level aboveground biomass in even- and uneven-aged management. Even-aged management is represented by three age classes $(20,40,60$ years) of equal area, and uneven-aged management is represented by one diameter distribution which remains constant along time

slope coefficients with values not far from those expected from the theoretical $8 / 3$ global allocation rule (West et al. 1999; Enquist and Niklas 2001). However, they were closer to the average empirical power value (2.37) obtained by Zianis and Mencuccini (2004) for numerous tree species and forest ecosystems throughout the world. Návar (2009, 2010) suggested that since empirically obtained model parameters seem to provide better biomass estimates, further research is needed for the development of theoretical allometric models based for instance on fractal geometry. The coefficients accompanying the predictor under the model form of Eq. 11 were of similar magnitude as the ones reported by Muukkonen (2007) for some tree species in Europe. 
4.2 Tree- and stand-level differences: implications in biomass and carbon prediction

The countries in which the data for this research were collected have followed different forest policies and practices which, in turn, have had an impact on P. brutia stand dynamics and structure. In Lebanon, selection cuttings aiming at harvesting the "best" pines were common until the beginning of the 1990s. On the contrary, large-scale harvesting activities on coniferous forests of Syria seem to have ceased much earlier. As a consequence of this, pine stands in Syria are more dense and even-aged, whereas the Lebanese stands present different degrees of "uneven agedness" resulting in higher within-stand heterogeneity in terms of tree size and shape (de-Miguel et al. 2010, 2012b). The determination of differences in stand structure based on statistical criteria such as standard deviation and skewness (Fig. 1) of the stand diameter distribution is consistent with the methods utilized by Burrows et al. (2002) to assess the effect of stand structure on carbon stock.

In combination with forest fires and environmental factors, past management has led to significant differences in the amount of biomass and carbon accumulated in different tree components (Fig. 3). On the other hand, despite the trees were significantly $(p<0.05)$ shorter in Lebanon than in Syria at a given dbh (Fig. 5), the total aboveground biomass of trees of equal dbh was nearly the same in both countries. The crown ratio was significantly higher for pines growing in the sparse and more uneven-aged stands of Lebanon (Fig. 5). As a result, trees growing in uneven-aged stands had more biomass and carbon in their crown components (needles and branches) than trees growing in unthinned and even-aged Syrian stands. Since the crown length of trees of same dbh was not different between Syria and Lebanon (Fig. 5), these results show that tree crowns are wider and/or denser in the uneven-aged Lebanese stands and that the allometric relations are sensitive to past growing conditions. Consequently, the biomass and carbon stored in the stem of trees is lower in uneven-aged stands than in even-aged stands (Figs. 2 and 3). The crown/ stem biomass ratio (Fig. 2) decreases as dbh increases and tends to stabilize when dbh attains between $15 \mathrm{~cm}$ in Syria and $30 \mathrm{~cm}$ in Lebanon. In Hemery et al. (2005), the crown/stem diameter ratio tended to stabilize around $30-\mathrm{cm} \mathrm{dbh}$. Kuuluvainen (1991) also found that the proportion of stem biomass from total aboveground biomass (so-called harvest index) increased from smaller to larger trees and then stabilized. This reflects, in line with the pipe-model theory (Mäkelä 1986), the increasing need for biomass allocation into stem at early stages of tree development until a balance between stem and crown biomass accumulation is achieved. The stabilized harvest index reported by Kuuluvainen (1991) for larger trees growing in even-aged Norway spruce stands (slightly higher than 0.8 ) is fairly similar to the one found in this study for even-aged $P$. brutia stands growing in Syria, whereas the harvest index of the multi-layered $P$. brutia stands in Lebanon is around 0.6.

The results suggest that forest management-induced stand structure may have a significant influence on the way biomass and carbon are distributed within the tree since, depending on the resulting stand structure, trees adopt different ways to allocate biomass and carbon (Tinker et al. 2010). The results are consistent with current biological knowledge on stand dynamics of light-demanding species. Namely, trees growing in unthinned dense even-aged stands are expected to have longer stems and smaller crowns as a result of competition for light. Dominant trees growing under strong competition in even-aged stands are expected to have relatively small branch and foliage biomass (Návar 2009). In selectively cut unevenaged stands, dominant trees experience less competition and can further develop their crowns (Naidu et al. 1998; Jenkins et al. 2003). This may happen especially when the stand density has been low for a long time. High competition at young ages would most probably result in shorter crowns and thinner branches also in uneven-aged stands (Pukkala et al. 1992; Hynynen 1995; Hasenauer and Monserud 1996). Similarly, if an even-aged stand is sparse at young age, which is the case in tree plantations, tree crowns are probably larger than in dense naturally regenerated even-aged stands. Due to the low shade tolerance of $P$. brutia, uneven-aged stands are not likely to be associated with high stand densities of the dominant canopy layer, but even-aged stands may have low density.

This suggests that, to correctly predict crown dimensions, it is important to know the past competition rather than current stand structure (Hynynen 1995). Since stem taper and $d / h$ ratio reflect the tree's past growing conditions, it is recommendable to use both dbh and height in biomass prediction in simulations where different management regimes are possible (Chave et al. 2005).

Previous research on P. brutia stand dynamics based on different and larger datasets throughout the same study area (de-Miguel et al. 2010) already revealed lower dominant heights for the Lebanese stands most likely owing to both anthropogenic reasons (past forest management oriented toward selection cuttings) and environmental factors (Lebanese P. brutia forests represent the southernmost limit of the natural distribution area of this species). This suggests that the results presented in this article reflect real forest stand conditions within the study region and contribute to corroborate that tree allometry is modulated by environmental factors and forest structure in different geographic locations (Palumets 1988; Feldpausch et al. 2011). Further comparisons with previous research for this species contribute to reinforce the conclusions of this study. For instance, analyses carried out in Turkey (Durkaya et al. 2009), where P. brutia forests are managed under even-aged schedules, showed lower crown biomass and higher stem biomass than in Greece (Zianis et al. 2011), where 

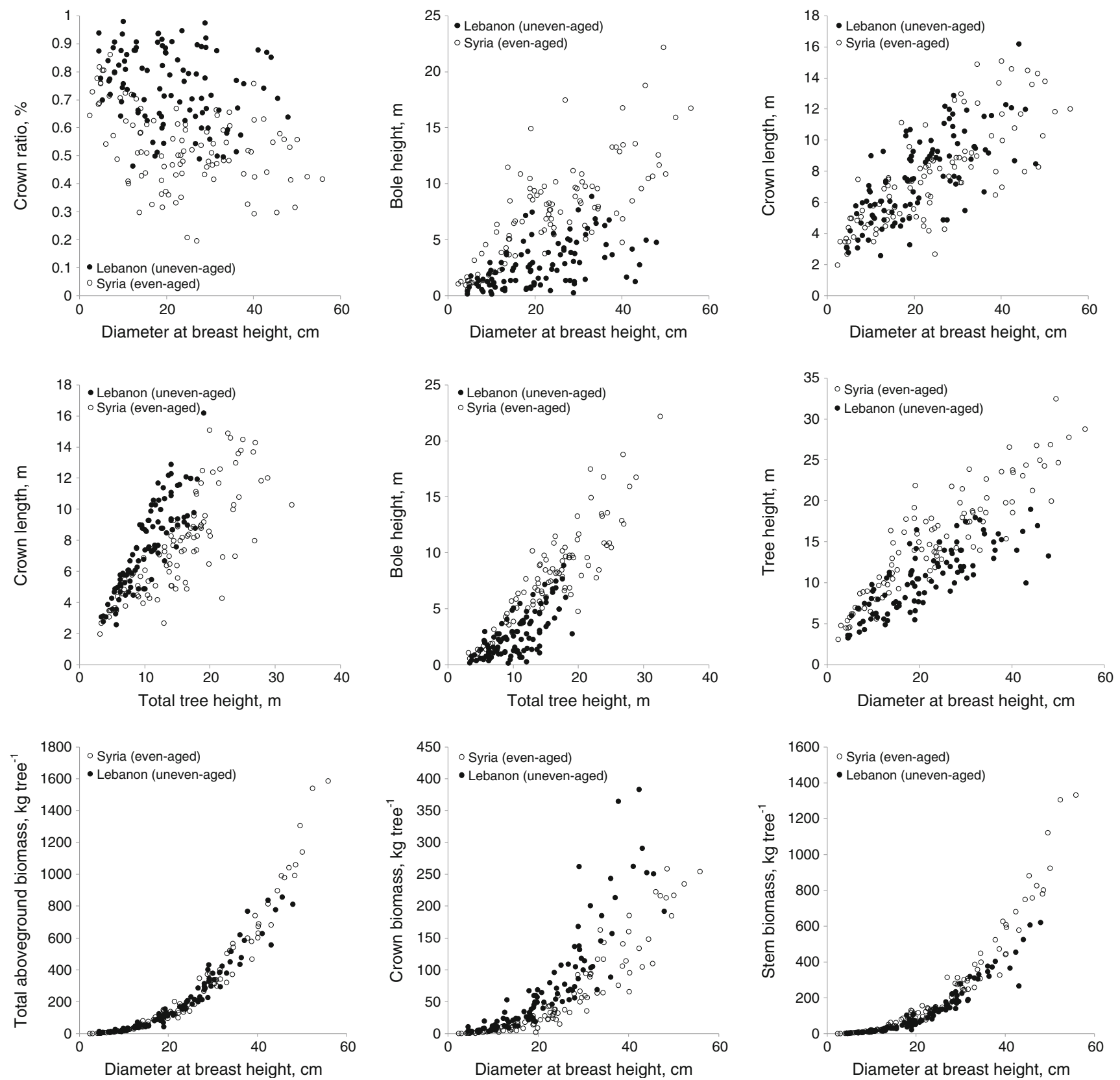

Fig. 5 Observations of trees growing in Syria and Lebanon revealing the main differences in tree size and shape according to crown length, bole height, crown ratio (defined as crown length divided by total height), height-diameter relationship, and biomass in different tree components

pine stands are characterized by a certain degree of uneven agedness (Palahí et al. 2008). Regarding the total (aboveground and belowground) biomass, the models of Montero et al. (2005) suggest that the share of root biomass of Mediterranean pines is typically about $35-38 \%$ of the total biomass, or 53-61\% of the above-ground biomass. These percentages could be used also for P. brutia if no better information is available.

The differences in biomass allocation found at tree level are propagated to stand and forest levels. Therefore, equivalent results, but not equal, to those reported at tree level were found when predicting forest-level biomass under different stand structures and management regimes (Fig. 4). These simulation results suggest that, at similar stand basal area, biomass and carbon stock are higher in forests populated by larger trees, as described by Balderas Torres and Lovett (2012). The main differences arise from the fact that the distribution of tree sizes varies according to stand structure, and biomass allocation depends on tree size (Fig. 2). Differences in crown and stem biomass and carbon between even-aged and uneven-aged stands can be very high in both absolute and relative terms. Moreover, using the "wrong" equations according to the stand structure may cause significant over- and under-estimations of biomass and carbon in different components at different scales 
(tree, stand, forest, etc.). For example, using the "uneven-aged equations" in an even-aged stand of $25 \mathrm{~m}^{2} \mathrm{ha}^{-1}$ in basal area produced overestimation of $104.6 \%$ in crown biomass and underestimation of $25.3 \%$ in stem biomass when compared to the prediction based on the correct allometric model (the one fitted for even-aged stands). Similarly, using the "even-aged equations" in an uneven-aged stand of $25 \mathrm{~m}^{2} \mathrm{ha}^{-1}$ in basal area resulted in $51.8 \%$ underestimation of crown biomass and in $32.2 \%$ overestimation of stem biomass. In the same vein, the "average" models for Middle East based on pooled data from Syria and Lebanon and using dbh as the only predictor may be unbiased at the regional scale, but result in biased predictions at the country level (Fig. 3).

The total aboveground biomass estimates did not differ significantly at tree level, which suggests that, if the aim is predicting total aboveground biomass, there is probably no need to consider different allometric models for different stand structures and management schedules. However, this is not usually the case in contemporary multi-objective forest management and planning where predictions of biomass and carbon in separate components are required for instance to assess fire risk and intensity, to predict the amount of cutting residues in carbon balance calculations or to estimate carbon emissions from forest degradation related to the differential use of tree components (e.g., selective logging of branches to collect fuelwood by rural communities).

In combination with models for even-aged and unevenaged $P$. brutia stand dynamics (de-Miguel et al. 2010, 2012b; Shater et al. 2011), the allometric equations provided in this study can be used to predict above-ground biomass and carbon stock under different forest management scenarios. Together with taper equations for the same species (de-Miguel et al. 2012a), they can be used to assess how much carbon is sequestrated in different timber assortments. The results presented in this article are based on country-specific data, which are required in national greenhouse inventories with higher methodological complexity (IPCC 2006; Henry et al. 2011). In this regard, the results of this study are also relevant within the framework of the IPCC guidelines (IPCC 2006) to the adoption of high-resolution and country-specific methods to estimate forest carbon, namely tier 2 (for national level) and tier 3 (for local-level forest modeling). Providing stand structure-sensitive models has much ado with increasing the degree of localization when fitting localized allometric equations and yielding predictions. Local allometric models most likely provide accurate aboveground biomass estimates, and if based on large enough and balanced samples, they may contribute to decrease the level of uncertainty in biomass and carbon prediction at forest and landscape levels (van Breugel et al. 2011). On the other hand, using stand variables which can be affected by forest management operations as predictors in biomass models results in instant changes in predicted biomasses. Therefore, models used in simulation should not use such variables, but only tree-level predictors (i.e., dbh, tree height, crown dimensions).

Acknowledgments Data collection was supported by Agencia Española de Cooperación Internacional para el Desarrollo (AECID) and Fundación Biodiversidad. The authors wish to thank the Ministries of Agriculture of the Governments of Lebanon and Syria as well as the Forest Sciences Centre of Catalonia (CTFC) for their precious collaboration.

\section{References}

António N, Tomé M, Tomé J, Soares P, Fontes L (2007) Effect of tree, stand and site variables on the allometry of Eucalyptus globulus tree biomass. Can J For Res 37:895-906

Balderas Torres A, Lovett JC (2012) Using basal area to estimate aboveground carbon stocks in forests: La Primavera Biosphere's Reserve, Mexico. Forestry 86:267-281

Baskerville GL (1972) Use of logarithmic regression in the estimation of plant biomass. Can J For Res 2:49-53

Bilgili E, Kucuk O (2009) Estimating above-ground fuel biomass in young calabrian pine (Pinus brutia Ten.). Energy Fuel 23:17971800

Bragg DC, Guldin JM (2010) Estimating long-term carbon sequestration patterns in even- and uneven-aged southern pine stands. In: Jain TB, Graham RT, Sandquist J (eds) Integrated management of carbon sequestration and biomass utilization opportunities in a changing climate: Proceedings of the 2009 National Silviculture Workshop; 2009 June 15-18; Boise, ID. Proceedings RMRS-P-61. U.S. Department of Agriculture, Forest Service, Rocky Mountain Research Station, Fort Collins, pp 111-123

Bravo F, Bravo-Oviedo A, Diaz-Balteiro B (2008) Carbon sequestration in Spanish Mediterranean forests under two management alternatives: a modeling approach. Eur J For Res 127:225-234

Burrows WH, Henry BK, Back PV, Hoffmann MB, Tait LJ, Anderson ER, Menke N, Danaher T, Carter JO, McKeon GM (2002) Growth and carbon stock change in eucalypt woodlands in northeast Australia: ecological and greenhouse sink implications. Glob Chang Biol 8:769-784

Chave J, Andalo C, Brown S, Cairns MA, Chambers JQ, Eamus D, Fölster H, Fromard F, Higuchi N, Kira T, Lescure JP, Nelson BW, Ogawa H, Puig H, Riéra B, Yamakura T (2005) Tree allometry and improved estimation of carbon stocks and balance in tropical forests. Oecologia 145:87-99

Chave J, Condit R, Aguilar S, Hernandez A, Lao S, Perez R (2004) Error propagation and scaling for tropical forest biomass estimates. Phil Trans R Soc Lond B 359:409-420

Crow TR (1978) Common regressions to estimate tree biomass in tropical stands. For Sci 24:110-114

de-Miguel S, Mehtätalo L, Shater Z, Kraid B, Pukkala T (2012a) Evaluating marginal and conditional predictions of taper models in the absence of calibration data. Can J For Res 42:1383-1394

de-Miguel S, Pukkala T, Assaf N, Bonet JA (2012b) Even-aged or uneven-aged modelling approach? A case for Pinus brutia. Ann For Sci 69:455-465

de-Miguel S, Pukkala T, Shater Z, Assaf N, Kraid B, Palahí M (2010) Models for simulating the development of even-aged Pinus brutia stands in Middle East. Forest Syst 19:449-457

del Río M, Barbeito I, Bravo-Oviedo A, Calama R, Cañellas I, Herrero C, Bravo F (2008) Carbon sequestration in Mediterranean pines forests. In: Bravo F, LeMay V, Jandl R, von Gadow K (eds) Managing forest 
ecosystems: the challenge of climate change. Springer, Berlin, pp 221-246, $338 \mathrm{p}$

Durkaya A, Durkaya B, Ünsal A (2009) Predicting the above-ground biomass of calabrian pine (Pinus brutia Ten.) stands in Turkey. Afr J Biotechnol 8:2483-2488

Enquist BJ, Niklas KJ (2001) Invariant scaling relations across treedominated communities. Nature 410:655-660

Feldpausch TR, Banin L, Phillips OL, Baker TR, Lewis SL, Quesada CA, Affum-Baffoe K, Arets EJMM, Berry NJ, Bird M, Brondizio ES, de Camargo P, Chave J, Djagbletey G, Domingues TF, Drescher M, Fearnside PM, França MB, Fyllas NM, Lopez-Gonzalez G, Hladik A, Higuchi N, Hunter MO, Iida Y, Salim KA, Kassim AR, Keller M, Kemp J, King DA, Lovett JC, Marimon BS, Marimon-Junior BH, Lenza E, Marshall AR, Metcalfe DJ, Mitchard ETA, Moran EF, Nelson BW, Nilus R, Nogueira EM, Palace M, Patiño S, Peh KSH, Raventos MT, Reitsma JM, Saiz G, Schrodt F, Sonké B, Taedoumg HE, Tan S, White L, Wöll H, Lloyd J (2011) Height-diameter allometry for tropical forest trees. Biogeosciences 8:1081-1106

Gauch HG, Hwang JTG, Fick GW (2003) Model evaluation by comparison of model-based predictions and measured values. Agron J 95: $1442-1446$

Gray KL, Reinhardt ED (2003) Analysis of Algorithms for predicting canopy fuel. In: Proceedings of the Second International Wildland Fire Ecology and Fire Management Congress and Fifth Symposium on Fire and Forest Meteorology, November 16-20, 2003, Orlando, FL. American Meteorological Society, p 5.8

Guller B (2007) The effects of thinning treatments on density, MOE, MOR and maximum crushing strength of Pinus brutia Ten. wood. Ann For Sci 64:467-475

Hasenauer H, Monserud RA (1996) A crown ratio model for Austrian forests. For Ecol Manage 84:49-60

Hemery GE, Savill PS, Pryor SN (2005) Applications of the crown diameter-stem diameter relationship for different species of broadleaved trees. For Ecol Manage 215:285-294

Henry M, Picard N, Trotta C, Manlay RJ, Valentini R, Bernoux M, SaintAndré L (2011) Estimating tree biomass of Sub-Saharan African forests: a review of available allometric equations. Silva Fenn 45: $477-569$

Hynynen J (1995) Predicting tree crown ratio for unthinned and thinned Scots pine stands. Can J For Res 25:57-62

Intergovernmental Panel on Climate Change (IPCC) (2006) IPCC guidelines for national greenhouse gas inventories, prepared by the National Greenhouse Gas Inventories Programme, Eggleston HS, Buendia L, Miwa K, Ngara T, Tanabe K (eds). IGES, Japan

Isik F, Isik K, Lee SJ (1999) Genetic variation in Pinus brutia Ten. in Turkey: I. growth, biomass and stem quality traits. For Genet 6:89-99

Jenkins JC, Chojnacky DC, Heath LS, Birdsey RA (2003) National-scale biomass estimators for United States tree species. For Sci 49:12-35

Ketterings QM, Coe R, van Noordwijk M, Ambagau Y, Palm CA (2001) Reducing uncertainty in the use of allometric biomass equations for predicting aboveground tree biomass in mixed secondary forests. For Ecol Manage 146:199-209

Kuuluvainen T (1991) Relationships between crown projected area and components of above-ground biomass in Norway spruce trees in even-aged stands: empirical results and their interpretation. For Ecol Manage 40:243-260

Küçük Ö, Bilgili E (2007) Crown fuel load for young calabrian pine (Pinus brutia Ten.) trees. J For Fac Kastamonu Uni-Kastamonu 7:180-189

Küçük Ö, Bilgili E, Saglam B (2008) Estimating crown fuel loading for Calabrian pine and Anatolian black pine. Int J Wildland Fire 17: $147-154$

Marklund LG (1987) Biomass functions for Norway spruce (Picea abies (L.) Karst.) in Sweden. Sveriges lantbruksuniversitet RapporterSkog 43:1-127

Marklund LG (1988) Biomassafunktioner för tall, gran och björk i Sverige. Sveriges lantbruksuniversitet Rapporter-Skog 45:1-73
Montero G, Ruiz-Peinado R, Muñóz M (2005) Producción de biomasa y fijación de $\mathrm{CO}_{2}$ por los bosques españoles. Monografias INIA nO 13

Muukkonen P (2007) Generalized allometric volume and biomass equations for some tree species in Europe. Eur J For Res 126:157-166

Mäkelä A (1986) Implications of the pipe model theory on dry matter partitioning and height growth in trees. J Theor Biol 123:103-120

Naidu SL, DeLucia EH, Thomas RB (1998) Contrasting patterns of biomass allocation in dominant and suppressed loblolly pine. Can J For Res 28:1116-1124

Návar J (2009) Allometric equations for tree species and carbon stocks for forests of northwestern Mexico. For Ecol Manage 257:427-434

Návar J (2010) Measurement and assessment methods of forest aboveground biomass: a literature review and the challenges ahead. In: Momba M, Bux F (eds) Biomass. Sciyo, Croatia, pp 27-64

Palahí M, Pukkala T, Kasimiadis D, Poirazidis K, Papageorgiou AC (2008) Modelling site quality and individual-tree growth in pure and mixed Pinus brutia stands in north-east Greece. Ann For Sci 65:501

Palumets YK (1988) Distribution of Norway spruce phytomass fractions as a function of age and climatic factors. Soviet Forest Sci 2:34-40

Parresol BR (2001) Additivity of non-linear biomass equations. Can J For Res 31:865-878

Peichl M, Arain MA (2007) Allometry and partitioning of above- and belowground tree biomass in an age-sequence of white pine forests. For Ecol Manage 253:68-80

Porté A, Trichet P, Bert D, Loustau D (2002) Allometric relationships fro branch and tree woody biomass of maritime pine (Pinus pinaster Ait.). For Ecol Manage 158:71-83

Pukkala T, Karsikko J, Kolström T (1992) A spatial model for the diameter of thickest branch of Scots pine. Silva Fenn 26:219-230

Pukkala T, Lähde E, Laiho O, Salo K, Hotanen JP (2011) A multifunctional comparison of even-aged and uneven-aged forest management in a boreal region. Can J For Res 41:851-862

R Development Core Team (2011) R: a language and environment for statistical computing. R Foundation for Statistical Computing, Vienna. ISBN 3-900051-07-0. http://www.R-project.org/

Repola J (2009) Biomass equations for Scots pine and Norway spruce in Finland. Silva Fenn 43:625-647

Shater Z, de-Miguel S, Kraid B, Pukkala T, Palahí M (2011) A growth and yield model for even-aged Pinus brutia stands in Syria. Ann For Sci 68:149-157

Snowdon P, Eamus D, Gibbons P, Khanna PK, Keith H, Raison RJ, Kirschbaum MUF (2000) Synthesis of allometrics, review of root biomass and design of future woody biomass sampling strategies. National Carbon Accounting System Technical Report 17. Australian Greenhouse Office, Canberra, 114 p

Ter-Mikaelian MT, Korzukhin MD (1997) Biomass equations for sixtyfive North American tree species. For Ecol Manage 97:1-24

Tinker D, Stakes GK, Arcano RM (2010) Allometric equation development, biomass, and aboveground productivity in Ponderosa pine forests, Black Hills, Wyoming. West J Appl For 25:112-119

van Breugel M, Ransijn J, Craven D, Bongers F, Hall JS (2011) Estimating carbon stock in secondary forests: decisions and uncertainties associated with allometric biomass models. For Ecol Manage 262:1648-1657

West GB, Brown JH, Enquist BJ (1999) A general model for the structure and allometry of plant vascular systems. Nature 400:664-667

Zianis D, Mencuccini M (2004) On simplifying allometric analyses of forest biomass. For Ecol Manage 187:311-332

Zianis D, Muukkonen P, Mäkipää R, Mencuccini M (2005) Biomass and stem volume equations for tree species in Europe. Silva Fenn Monographs 4, $63 \mathrm{p}$

Zianis D, Xanthopoulos G, Kalabodikis K, Kazakis G, Ghosn D, Roussou O (2011) Allometric equations for aboveground biomass estimation by size class for Pinus brutia Ten. trees growing in North and South Aegean Islands, Greece. Eur J For Res 130: $145-160$ 